\title{
二つの絶縁物壁面が作る微小間隙内を貫く 交流絶縁破壊
}

\author{
正員山野芳昭 (千葉大)
}

AC Breakdown through Narrow Chink between Two Insulating Walls.

Yoshiaki Yamano, Member (Chiba University)

\begin{abstract}
$\mathrm{AC}$ breakdown and ac partial discharge through narrow chink between two insulating walls were investigated, using a (knife edge)/(plane) electrode configuration. The chink was formed by two plane walls of PE insulator blocks. The maximum electrode distance studied was $70 \mathrm{~mm}$. The experiments were performed in air controlled at $20-25^{\circ} \mathrm{C}$ and $40-50 \%$ RH.
\end{abstract}

$\mathrm{AC}$ breakdown characteristics depend on width(s) of the chink: In a range of the width(s) about $1 \mathrm{~mm}<\mathrm{s}<20 \mathrm{~mm}$, the breakdown voltage decreases with the decrease in the width(s); In the range between about $100 \mu \mathrm{m}<\mathrm{s}<1 \mathrm{~mm}$, the voltages are higher than that at $2 \mathrm{~mm}$ of the width(s); In the range between about $15 \mu \mathrm{m}<\mathrm{s}<100 \mu \mathrm{m}$, the voltage decreases with the decrease in the width(s). It was found that these breakdown characteristics are corresponding to the dependence of ac partial discharge characteristics on the width of the chink: $\mathrm{AC}$ breakdown voltage is decreased with increases in the number and the maximum strength of positive pulse in ac partial discharges generated near the positive peak of ac applied voltage. The discussion was focused on the dependence of the number and the strength of the positive pulse on the width of the chink.

キーワート：交流絶縁破壊, 沿面絶縁, 微小間隙, 部分放電

\section{1.はじめに}

高電圧機器等における複合絶縁化が促進されるにともな い(1，2)、二つの固体絶縁物が互いに接触する箇所が増加す

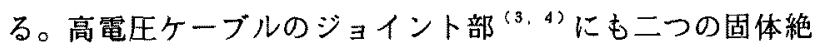
縁物(絶縁被覆贋)の接触がみられる。通常このような接触 部は絶縁物表面同士を密着させて、接触部に間隙ができな いような措置が採られている(3)。絶縁物表面同士が完全に 密着している限り、密着箇所の絶縁耐力はあまり低下しな い(4)。しかし、運転中の振動, 熱, 絶縁物の経年劣化などが 原因となって、接触部に微小な間隙が生じる場合がある。 このような微小間腺を構成する絶縁物壁面に沿って電界が 印加されていると、壁面に沿って部分放電が進展し、絶縁 耐力の低下を招くことが予想される。

絶縁物同士が作る微小間陌は、二つの絶縁物表面が近い 距離に接近した状態と見なすことができる。絶縁物表面上 に発生する沿面部分放電の場合、沿面部分放電の伸びは絶 縁物表面に带電・蓄樻する電荷(沿面部分放電によって生じ た電荷)の分布状態に大きく影響を受ける(5)。それに伴っ て、沿面絶縁耐力も大きく変化する。直流やインパルス課
電の場合、帯電・蓄積する電荷はおおむね単極性であるので、 電荷の带電・蓄積が沿面部分放電の伸びに与える影響も比較 的予想しやすい。一方、交流課電の場合は、印加電圧の極 性が時間的に変化するので、帯電・蓄積する電荷の分布状態 が複雑となり、それに伴って部分放電の発生形態も複雑に 変化を受ける。たとえば、交流沿面部分放電の発生形態や 絶縁物表面に帯電する電荷(部分放電によって生じたもの) の分布状態は絶縁物の種類に依存し、䋓縁物の種類によっ ては絶縁物表面を伸びやすい形態の交流部分放笔が発生し、 交流沿面絶縁耐力も大き〈低下する ${ }^{(6)}$ 。微小間吵内の壁面 に沿って発生する部分放電の伸びや絶縁破壊も、間隙を形 成する絶縁物壁面に帯電・蓄樍する電荷の影響を受けるもの と考えられる。しかし間隙を形成する二つの絶縁物壁面の 距離が短くなると、二つの絶縁物壁面に带電・蓄積した電荷 が狭い空間を伸びる部分放電に作用を及ぼすことになる。 また微小間隙の絶縁物壁面に帯電・蓄積する電荷の状態は、 大気中におかれた絶縁物表面における带電・付着状態と晎な ることも考えられる。したがって微小間隙内の壁面を伸び る交流部分放電および交流絶縁破壊特性は、通常の交流沿 面部分放電の特性からは単純には予想できない可能性があ 
る。微小間隙を形成する絶縁物壁面に沿って生じる交流部 分放電や交流絶縁破壊について検討した例は、過去にはほ とんど報告されていない。これと似た例としては、絶縁物 中のトリ一細管を模擬する目的で固体絶縁物中に細管を設 け、細管の内壁に洽った絶縁矿力特性についての報告があ る 7-8)。しかし、これらの論文では交流課電における部分 放電特性や破壊電圧特性に関する実験結果について詳しく 検討されておらず、微小間隙に沿った交流破壊特性を予測 することは難しい。このようなことから、本論文では不平 等電界下で(部分放電が発生しやすい状況)、二つの固体絶 縁物が作る微小間隙を貫く交流絶縁破壊について、間隙幅 を変化させながら、交流部分放電の発生特性と関連付けて 検討を行った。

\section{2. 実験方法}

図 1 に実験装置ならびに試料形状の概略を示す。接地平 板電極の上に二つの絶縁物のブロックを置き、図1(a)に示 す微小間吵を構成したものを試料とした。使用した絶縁物 は低密度ポリエチレン $(\mathrm{PE})(60 \mathrm{~mm} \times 40 \mathrm{~mm} \times \mathrm{d}$ ， d: 電極間隔)で ある。電極間隔(d)の最大長は70mmである。PEブロックはフ ライス盤で削り出した後、貴金属用の研磨布を用いて研磨 した。微小間腺を構成する二つのPEブロック壁面は、平均 粗さ $\pm 0.4 \mu \mathrm{m}$ 、最大粗さ $\pm 2.5 \mu \mathrm{m}$ 以内(表面粗さ計にて測定， 測定精度: $0.01 \mu \mathrm{m}) に$ 仕上げた。PEブロック各面の平行度お よび寸法の規定值に対する偏差をマイクロメータおよびダ イヤルゲージによって測定した結果、それらは壁面の最大 粗さ以内であった。

また絶縁物試料として、図 1(b)のように絶縁物ブロック， の一部を切りとって空間を作り、微小間隙と空間とを高電 圧刃形電極と接地平板電極との間に直列に配置したものも 用いた。この試料における放電路は、刃形電極一微小間隙 一空間を通り接地電極へ至る。このような試料を用いた主 な理由は、高電圧刃形電極先端から離九た場所における絶 縁物壁面の有無が絶縁破壊特性に及ぼす影響を調べるため である。

微小間隙の幅 $(\mathrm{s})$ は $15 \mu \mathrm{m} \sim 20 \mathrm{~mm}$ 範团で変化させた。間 隙幅の調整に際して、設定する間隙幅と同じ厚さを持つ絶 縁性フィルム片(あるいは絶縁物)二枚を、スペーサとして、 間隙を構成するブロック面に挟んだ後、PEブロックを接地 板電極に固定した。スペーサの形状及び挿入位置を図 1 (c) に示す(図は代表例として空間が存在しない試料の場合を示 している)。間隙にスペーサを挟むことによって、放電特性 が変化しないことは確認してある。

交流 $(50 \mathrm{~Hz})$ 高電圧を印加する電極として、刃形電極(図1 (a))(オルファ(株)製, 品番:XB56, 材質:SK-2炭素工具鋼)を 使用した。不平等電界を形成させるには、一般には針電極 の使用も考えられる。しかし針電極を使用した場合、間隙 幅が狭くなると、針電極先端を間隙の中心に配置するのが 困難となる理由から、本実験では刃形電極を用いた。使用 した刃形電極の雨端は、そこからフラッシオーバが生じな (a)

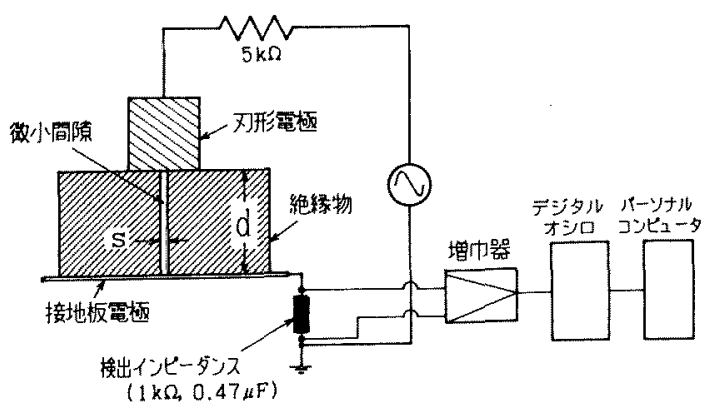

(b)
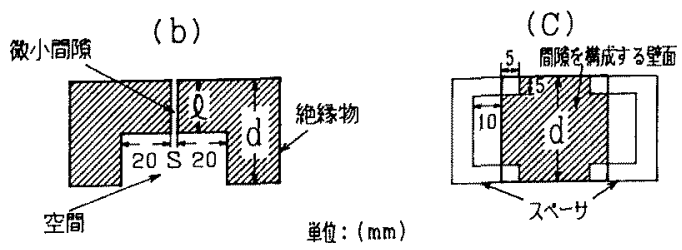

図 1 測定装置および試料

(a)-一測定装置および空間の存在しない試料,

(b) - - 空間の存在する試料, (c)-ースペーサと挿入 位置(空間の存在しない試料の場合), $\ell$ :間隙長， $\mathrm{s}$ :間隙幅, d:電極間隔

Fig.1. Experimental Apparatus and Specimen. (a) - - Experimental apparatus and specimen without space, (b)--Specimen with space, (c)--Spacer and its position.

$\ell$ :Length of chink, $s:$ Width of chink, $\mathrm{d}$ : Electrode distance.

いように、丸みをもたせてある。交流破壊電圧の測定で は、まず刃形電極への交流印加電圧を一定速度 $(300 \mathrm{~V} / \mathrm{sec})$ で上畕させて、破壊に至った時点の印加電压の值を測定し た。同一条件の試料 10 組を用い、各試料每に1分間隔で連続 10 回の測定を行った。測定した值(デー夕数 =100)を平均し て交流破壊電压を求めた。なお、放電による試料の劣化を 防ぐため、絶縁破壊に起因して 0.3 A以上の電流が流れる と10ms以内に交流印加電压が遮断できるようになっている。 部分放電パルスの測定では、発生パルス数および放電䉓 荷(見かけの放電電荷) と印加電圧の位相との関係を求めた。 図 1 (a)に示す検出インピーダンスによって検出した電流信 号は、增幅器を経由してデジタルオシロスコープに入る。 交流印加電圧1サイクル分の電流波形信号をデシタルオシロ スコープ内で数值化し、パーソナルコンピュータへ取り込 んだ。1つの条件の試料につき、この操作を5回(印加電压に して任意の5サイクル)繰り返した。5サイクル分の測定結果 を合計して、部分放電パルスの発生する印加電圧の位相と 放電電荷との関係を求めた。

また、微小間隙内に発生する交流部分放電によって間隙 を構成する絶縁物壁面に帯電・蓄積する電荷の分布状態をダ ストフィギュアによって観测した。使用した帯電粉は、正 帯電部分に赤色粉が、負帯電部分に青色粉が付着するむの 
である(10)。

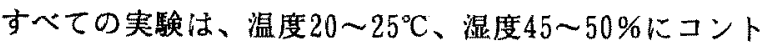
ロールされた室内で行った。

\section{3. 実験結果}

$<3 \cdot 1>$ 交流䎦椂破棲特性図 2 に交流絶縁破壊電死 の測定結果を示す。測定値のばらつきは測定值の $\pm 5 \%$ 以内 であったので、図中には、煩雑さを防ぐため、ばらつき範 囲を特には示していない。

まず空間が存在しない場合(図 1(a)の試料)における交流 破塤電压亡間隙幅 $(s)$ との関係について説明する。図 2 中 には、その代表例として電極間隔(d)が50mmの場合について 示してある(図中の曲線 $A$ )。間隙幅( $\mathrm{s}$ )の変化に伴って交 流破壊電任は以下のように贸化する。すなわち、間隙幅 $(\mathrm{s})$ の範囲がほぼ $1 \mathrm{~mm}<\mathrm{s}\langle 20 \mathrm{~mm}$ の領域( As 領域と呼ぶ)におい ては、sを狭くすると交流破壊電任は低下する。ほぼ100 $\mu \mathrm{m}<\mathrm{s}<1 \mathrm{~mm}$ の領域( Bs 領域と呼ぶ)における交流破壊電圧は、 $\mathrm{s}=2 \mathrm{~mm} \sim 3 \mathrm{~mm}$ のときと比べて高い值を示す。およそ $15 \mu \mathrm{m}<\mathrm{s}$ $<100 \mu$ mの領域 (Cs 領域亡呼ぶ)では、s を狭くすると、交 流破罣電圧は低下する。以上のように、染間が存在しない 試料における交流絶縁破壊電压と間隙幅( s ) との関係は、 三領域のsで巽なる傾向を示すことがわかった。

次に空間が存在する場合(図 1(b)の試料)について説明す る。電極間隔(d)が一定の状態で間隙長( 凤)を短くすると、 前述した”sの三領域で交流破堘電圧特性が異なる傾向”が 薄孔てくる。本実娩の電極間隔(d)の範团において、りが約 (1/2)dよりも長い場合、たとえば図 2 の $=15 \mathrm{~mm} ３ \mathrm{~mm} の$ 特 性が示すように、s狭くすると交流破壊䉓压はおよそ

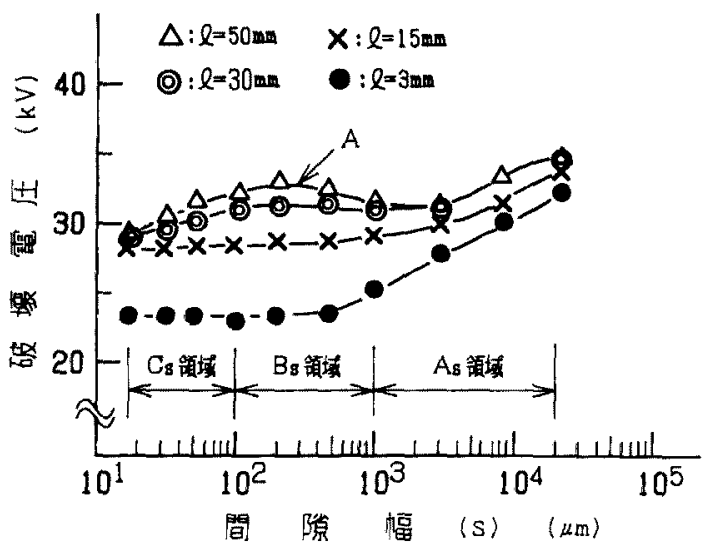

図 2 交流破壊電圧と間隙幅 (s) との関係 電極間隔 $(d)=50 \mathrm{~mm}, \ell$ : 間隙長, $A$ : 空間の存在し ない試料の特性

Fig.2. Relations between ac breakdown voltage and width(s) of chink.

Electrode distance $(d)=50 \mathrm{~mm}, \quad \ell$ :Length of chink, A:Specimen without space.
As 領域でのみ低下する傾向を示すようになる。なお実験を 行ったsの範囲においては、りを短くすることによって、 交流破壊電压は低下する傾向を示す。

以上のように、交流絶縁破壊特性の間吵幅( $s$ )に対する 依存性を、三つの領域のs（As, BsおよびCs頒域)に分け て説明した。しかし、図2 からもわかるように、交流絶縁 破壊特性は各sの領域の境界を境に明確に変化するわけで はない。本論文では、論旨を分かりやすくするために、便 宜上s 三つの領域に分けて特性の説明を行う。

図 2 には代表例として電極間隔 $(d)=50 \mathrm{~mm}$ の場合について 示したが、上述したような交流破壊電生の間隙䒇( $\mathrm{s}$ )に対 する依存性および間腺長( と)に対する依存性は、15mm<d< $70 \mathrm{~mm}$ 範囲で観測される。

絶縁破境発生時の交流印加電圧の位相をデジタルオシロ スコープで観測したところ、実験を行った範囲における絶 縁破壊は、すへて交流印加電圧の正のピーク付近(印加電压 の位相で $(2 \pi / 5) \sim(3 \pi / 5)$ 範囲)で発生している。

〈3・2〉交流部分放電特性 図 3 に空間が存在しない 試料(図 1(a))における交流部分放電の放電電荷(見かけの 放電電荷)と印加電圧位相との関係を示す。図は印加電圧が $27 \mathrm{kV}$ よきの結果である。この印加電王值は、間隙幅 $(s)$ $=15 \mu \mathrm{m}$, 電極間陽 $(\mathrm{d})=50 \mathrm{~mm}$ におる交流破壊電压の約 $95 \%$ の値に相当する。また図には、放電電荷が士2 $2 \times 10^{-1}{ }^{\circ} \mathrm{C}$ 上 のパルスについて表示した。

図 3 のデータは、微小間隙以外の場所における部分放電 も一緒に計測している。しかし、微小間隙が存在しない状 態(对向する二つのPEブロック壁面同士を完全に接触させた 状態)で計測される部分放電は、その発生頻度及び放電䉓荷 ともに、微小間㗂が存在するときに計測される值の $20 \%$ 以 下であった。

図3の( a )，(b)はそれぞれ s が20mmおよび2mmの場合の

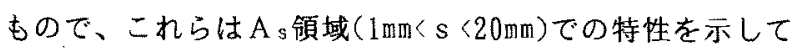
いる。この2つの図を比較するとわかるように、s が狭く なるにともなって、交流印加電压の正ピーク付近で発生す る正パルスの数, 放電電荷ともに多くなる傾向を示す。負パ ルスについては特に顕著な変化は認めら杖い。図 $30(\mathrm{c})$ はBs 領域における発生パルス特性の代表例を示したもので ある。 $\mathrm{s}=2 \mathrm{~mm}$ (図 $3(\mathrm{~b}): \mathrm{As}$ 領域)の場合亡比べると、交流 印加電俚の正ピーク付近で発生する正パルスの数, 放電電荷 ともに少なくなっている。負パルスについてはAs領域と比 較しても、特に顕著な変化は認められない。図 $3 の(d)$ は Cs領域における発生パルス特性の代表例を示したものであ る。 $\mathrm{B}$ s領域の場合(図 $3(\mathrm{C})$ ) と比べると、交流印加電圧の 正ピーク付近で発生する正パルスの数, 放電電荷ともに多い ことがわかる。また、交流印加電圧の負ピーク付近では放 電電荷の大き負パルス $\left(5 \times 10^{-9} \mathrm{C}\right.$ 上)の発生が見られる。 このような放電電荷の大きい負パルスの発生は $\mathrm{s}$ s 領域のみ で観測される。図 3 には代表例として電極間隔(d)が50mmの 場合について示しているが、间様の傾向が $15 \mathrm{~mm}<d<70 \mathrm{~mm}$ の範囲で観測される。 

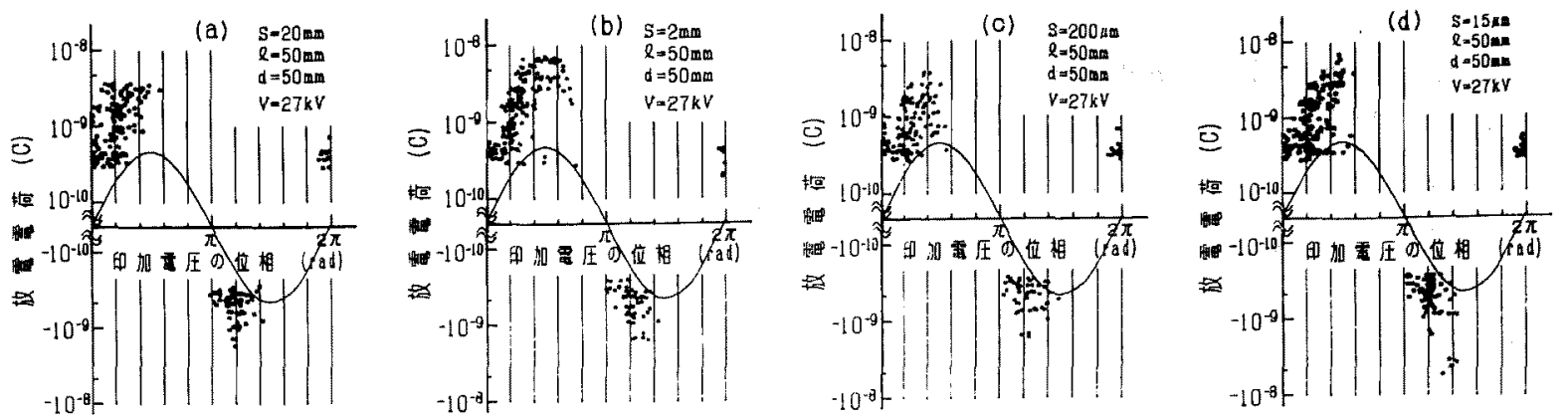

図 3 交流部分放電パルスの発生特性

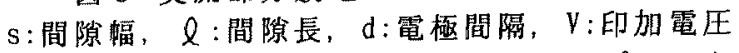

(印加電在 5 サイクル分の測定結果を合計してプロットした。)

Fig.3. Characteristics of ac partial discharges,

s:Width of chink, $\ell$ :Length of chink, d:Electrode distance, V:Applied voltage,

(Sum totals of pulses in five cycles of ac applied voltages are plotted.)

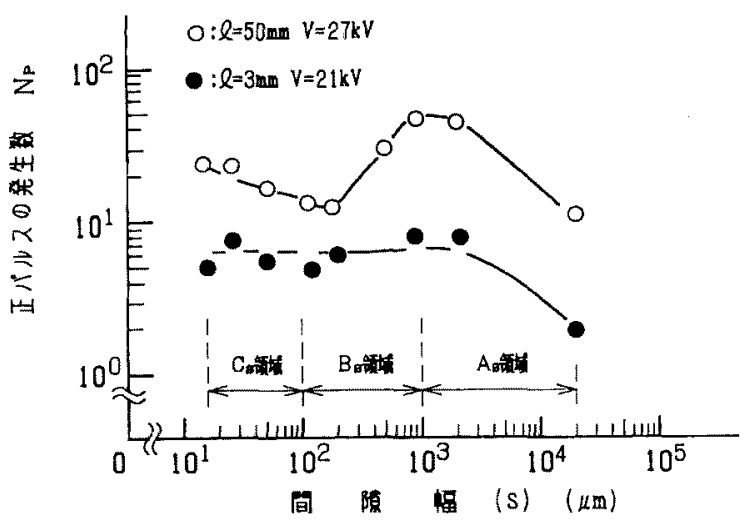

図 4 交流正パルスの発生数 $(\mathrm{Np})$ 亡間隙幅 ( S ) との関係

( Npは印加電圧 5 サイクル分の測定結果を合計し たもの） $\ell$ :間隙長, $V$ :印加電圧

Fig.4. Relations between number of positive pulses and width of chink under ac applied voltage.

(Np is sum totals of pulses detected in five cycles of ac applied voltages)

l :Length of chink, V:Applied voltage.

絶縁破壊は、実験を行ったすべてのs の範囲で交流印加 電圧の正ピーク付近で発生していることを考えると、正ピ 一ク付近で発生する正部分放電パルスの発生特性と交流絶 縁破罗特性とは密接な関係にあるあのと考えられる。そこ で、交流印加電圧の正ピーク付近 $((2 / 5) \pi<\theta<(3 / 5) \pi, \theta$ : 交流印加電圧の位相角)で発生する正パルスの発生数 $\left(N_{p}\right)$ および最大放電䉓荷 $\left(Q_{M}\right)$ と間隙幅 $(s)$ との関係を図 4, 図 5 に示した。 $\mathrm{NP}$ は放電電荷が $1 \times 10^{-8} \mathrm{C}$ 以上の正パルスの発 生数である。(発生頻度 $(\mathrm{n})$ に換算すると $\mathrm{n}=\mathrm{N}, \times 10$ (個/秒) である。 N P， QMCもに、破壊電压の粎95\%の印加電死に おける值である。図 4 , 図 5 に示す $\ell=50 \mathrm{~mm}$ の特性は空間

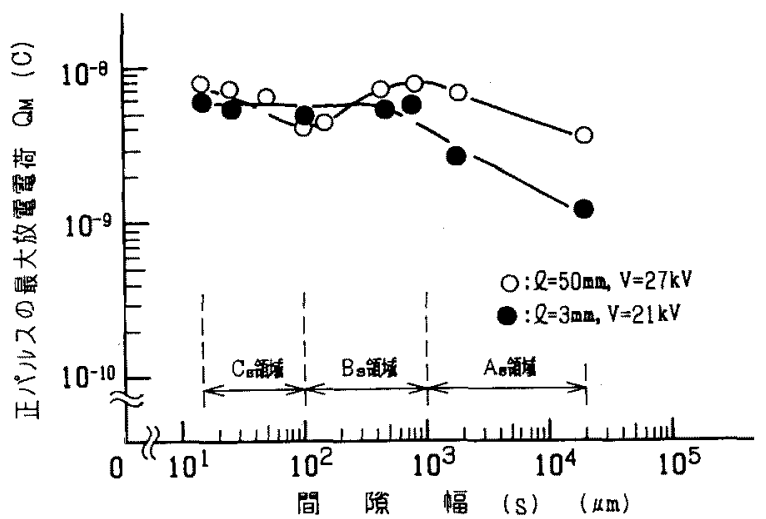

园 5 交流正パルスの最大放電電荷 $\left(Q_{M}\right)$ と間隙 幅 (S) Łの関係

（Qmは印加電圧 5 サイクル分の交流正パルスの 中での最大放電電荷を示す。)

८:間隙長, $V$ : 印加電圧

Fig.5. Relations between the maximum charge quantity of positive pulse and width of chink under ac applied voltage.

$\mathrm{Q}_{\mathrm{M}}$ is the maximum charge quantity in positive pulses detected in five cycles of ac applied voltage)

$\ell$ :Length of chink, V:Applied voltage.

が存在しない試料(図 1 (a))の場合であるが、空間が存在す る試料(図 1 (b))であっても、本実験の電極間嵒(d)の籍围

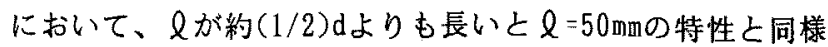
の傾向を示す。また $\ell=3 \mathrm{~mm}$ の特性は、空間が存在する試料 で $\ell<$ 約 $(1 / 2) \mathrm{d}$ 範囲での特性の代表例である。

図 4、図 5 に示すように、空間が存在しない試料 $(\ell=50$ $\mathrm{mm})$ および空間が存在する試料 $(\ell=3 \mathrm{~mm})$ よもに、A $\mathrm{s}, \mathrm{Bs}$, $C_{s}$ の各領域での $N_{P} \subset Q_{M}$ の変化特性は、図 2 に示した交流 破壊電圧の変化特性と相関性が見られる。すなわち、 $\ell=$ 
$50 \mathrm{~mm}$ よび $\ell=3 \mathrm{~mm}$ 両試料とも、 $\mathrm{N}$ p および $\mathrm{Q}$ Mが多くなる と、交流破壊電圧は低下している。これらのことから、交 流印加電圧の正ピーク付近で発生する正部分放電パルスの 発生数 $\left(\mathrm{N}_{\mathrm{P}}\right)$ および放電電荷 $\left(\mathrm{Q}_{\mathrm{M}}\right)$ が増加すると、それに起 因して交流破壊電圧が低下することが考えられる。

\section{4. 検 討}

本項では、交流部分放電の発生特性の間隙幅 ( s ) への依 存性について検討する。まず As 領域について考える。この 領域では、図 4 ，図 5 に示すように、空間が存在しない試 料(図 1 (a))および空間が存在する試料(図 1 (b))ともに、 $\mathrm{s}$ が狭くなると $\mathrm{N}_{\mathrm{P}}$ と $\mathrm{Q} \mathrm{M}$ は増加している。言い替えると、 $\ell=3 \mathrm{~mm}$ の状態であっても $\mathrm{s}$ が狭くなると $\mathrm{N}_{\mathrm{P}}$ と $\mathrm{Q}_{\mathrm{M}}$ は増加す る。すなわち、トリプルジャンクション(電極-絶縁物壁面 一気体が接触する部分)が存在していれば、間隙幅 $\mathrm{s}$ を狭く することにより、 $\mathrm{N}_{\mathrm{P}}$ と $\mathrm{Q}_{\mathrm{M}}$ が増加していることになるであ ろう。一般に、トリプルジャンクション部における部分放 電の発生密度は、他の部分よりも高い。A s 領域で $\mathrm{s}$ を狭く することは、ニつのトリプルジャンクション部が $1 \mathrm{~mm}$ 程度ま で接近することである。二つのトリプルジャンクションが 接近する $(\mathrm{s}$ を狭くする)ことによって電極先端近傍の部分 放電の密度が高くなり、その結果として $N_{\mathrm{P}}$ と $\mathrm{Q}_{\mathrm{M}}$ を増加さ せるもの之考えられる。

次に B s 領域および $\mathrm{C} s$ 領域について考える。3-2 項で説 明したように(図 4, 図 5 )、B $\mathrm{s}$ 領域およびCs 領域における $\mathrm{N}_{\mathrm{P}}$ と $\mathrm{Q}_{\mathrm{M}}$ の変化は、間隙長 $(\ell)$ が長いとき(本実験において は $\ell>$ 約 $(1 / 2) \mathrm{d}$ 範囲)にのみ観測される。すなわち、微小 間隙を構成する絶縁物壁面が電極先端から離れた場所に存

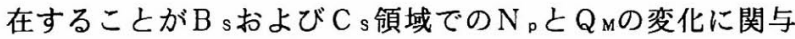
している可能性が高い。B $\mathrm{s}$ および $\mathrm{C} s$ 領域では、微小間隙 の幅が $1 \mathrm{~mm}$ 以上と狭いため、間隙内を通る部分放電の $\mathrm{N}$, と $\mathrm{Q}_{\mathrm{M}}$ は対向する二つの絶縁物壁面に蓄積した電荷の影響を受 やすくなるものと考えられる。そこで、絶縁物表面に帯電 ・蓄積する電荷の状態をダストフィギュアによって観測した。

図 6 は微小間隙を構成する絶縁物壁面のダストフィギュ アであり、Bsおよび $C_{s}$ の各領域のもの(それぞれ $s=200$ $\mu \mathrm{m}$ および $\mathrm{s}=15 \mu \mathrm{m})$ を示している。ダストフィギュアは、 部分放電が発生している状態(印加電圧は図 3 の測定時と同 じ值で、破壊電圧の約 $95 \%$ )で印加電圧を遮断した後に、作 成したものである。交流印加電圧の遮断は、正 $\rightarrow$ 負および 負 $\rightarrow$ 正のゼロクロスポイント（図中ではそれぞれ(t) $\rightarrow(-)$, $(-) \rightarrow(+)$ と標記)で行った。 $s=200 \mu \mathrm{m}$ の場合(B s 領域の場 合)、交流印加電圧の正 $\rightarrow$ 負のゼロクロスポイントでは赤色 粉の付着(正電荷の帯電(図中のP))が多く観測される。負 $\rightarrow$ 正のゼロクロスポイントでは、電極との接触部(写真のJ)付 近にわずかに青色粉の付着(負電荷の帯電 (図中のN))が観測 されるが、䉓極との接触部から離れた絶縁物壁面のほとん どの部分で赤色粉が付着(正電荷の帯電(図中のP))している。 すなわち交流正部分放電によって帯電した正電荷のうち、 電極との接触部(図中のJ)から離れた絶縁物壁面に帯電した

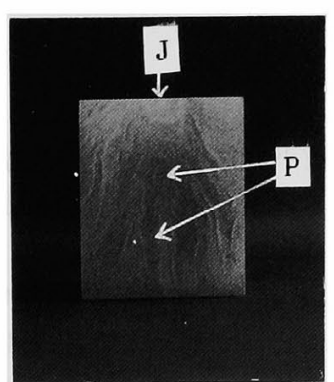

$(+) \rightarrow(-)$

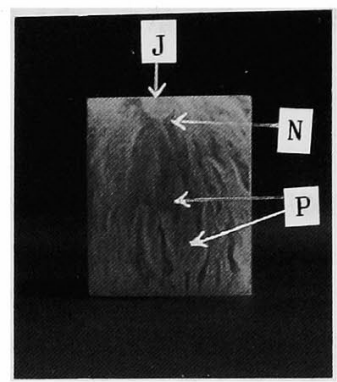

$(-) \rightarrow(+)$

间除幅 $(\mathrm{s})=200 \mu \mathrm{m}$

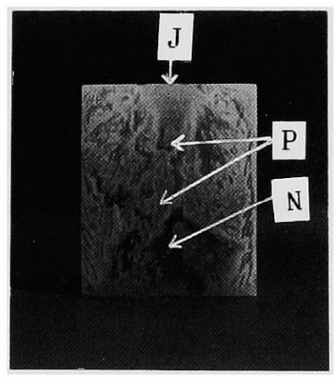

$(+) \rightarrow(-)$

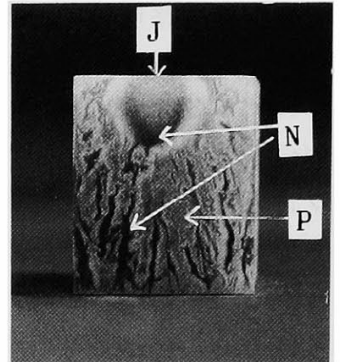

$(-) \rightarrow(+)$
间陵蝠 $(\mathrm{s})=15 \mu \mathrm{m}$

図 6 ダストフィギュアー 電極間隔 $(\mathrm{d})=$ 間隙長 $(l)=50 \mathrm{~mm}$, 印加電圧 $=27 \mathrm{kV}$ $\mathrm{P}$ : 正電荷の帯電, $\mathrm{N}$ :負電荷の帯電, $\mathrm{J}$ : 刃形電極 との接触点

Fig.6. Dust figures

Electrode distance $(d)=$ Length of $\operatorname{chink}(\ell)=50 \mathrm{~mm}$, $\mathrm{V}=27 \mathrm{kV}, \quad \mathrm{P}:$ Positively charged site,

$\mathrm{N}$ :Negatively charged site, J:Point where knife edged electrode is attached.

正帯電電荷のほとんどは、次に発生する交流負部分放電で 中和されずに残っていることを示しているものと考えられ る。この状態では、次に発生する交流正部分放電は絶縁物 壁面に残留している正帯電電荷の影響を受けて発生・進展が 抑制されるものと考えられる。

一方、 $\mathrm{s}=15 \mu \mathrm{m}(\mathrm{C} s$ 領域)における負 $\rightarrow$ 正のゼロクロスポ イントでは、電極との接触部から離れた絶縁物壁面で正・負 の両方の電荷(図中のPおよびN)の帯電が観測される。すな わち、C s 領域においては、交流負部分放電による正帯電電 荷の中和ならびに負電荷の帯電が、 $\mathrm{B} s$ 領域よりも優勢に行 われていることを示唆しているものと考えられる。このこ とは、部分放電特性(図 $3(\mathrm{~d})$ ) において、放電電荷の多い負 パルスの発生が $\mathrm{C} s$ 領域で観測される( B s 領域では観測され ない)ことからむ裹付けられる。したがって、Cs 領域では 交流負部分放電により絶縁物壁面に帯電している正電荷が ある程度中和されることによって、B s 領域よりも交流正部 分放電が発生・進展しやすくなるものと考えられる。このこ とが原因となって、C $\mathrm{s}$ 領域における交流破壊電圧が $\mathrm{B} s$ 領 
域よりも低い値を示すものと考えられる。

\section{5.まとめ}

絶縁物 (PE)の壁面で構成した微小間隙を貫く交流絶縁破 壊電圧は間隙幅 $(s)$ に依存することがわかった。その依存 性は、交流部分放電における正パルス(印加電圧の正のピー ク付近で発生するもの)の発生数と最大放電電荷の間隙幅の 変化への依存性と相関性がみられた。すなわち、正パルス の発生数と最大放電電荷が増加すると、交流破壊電圧が低 下する傾向を示す。以下に、本実験の範团において観測さ れた交流部分放電特性および交流絶縁破壊特性の間隙幅 $(s)$ への依存性を整理して、まとめとする。

\section{(1) $\ell>$ 約 $(1 / 2) \mathrm{d}$ 場合}

(a) $1 \mathrm{~mm}<\mathrm{s}<20 \mathrm{~mm}$ の領域： $\mathrm{s}$ の減少に伴って交流絶縁破壊電 圧が低下する。同じく $\mathrm{s}$ の減少に伴って、印加電圧の正ピ 一ク付近で発生する交流部分放電電流の正パルスの発生数, 最大放電電荷が增加する。負パルスについては特に顕著な 変化は認められない。

(b) $100 \mu \mathrm{m}<\mathrm{s}<1 \mathrm{~mm}$ 領域: 交流絶縁破壊電压は $\mathrm{s}=2 \sim 3 \mathrm{~mm}$ における值よりも高い。印加電圧の正ピーク付近で発生す る交流部分放電電流の正パルスの発生数, 最大放電電荷は $\mathrm{s}=2 \mathrm{~mm}$ 付近における值よりも減少する。負パルスについて は特に顕著な変化は認められない。

(c) $15 \mu \mathrm{m}<\mathrm{s}<100 \mu \mathrm{m}$ の領域： $\mathrm{s}$ の減少に伴って交流絶縁破 壊電圧が低下する。同じく $s$ の減少に伴って、印加電圧の 正ピーク付近で発生する交流部分放電電流の正パルスの発 生数, 最大放電電荷が増加する。他の $\mathrm{s}$ の領域では見られ なかった放電電荷の大きい負パルスの発生が観測される。

(2) $\ell<$ 約 $(1 / 2) \mathrm{d} の$ 場合

(a) $1 \mathrm{~mm}<\mathrm{s}<20 \mathrm{~mm}$ の領域： $\mathrm{s}$ の減少に伴って交流絶縁破壊電 圧が低下する。同じく $\mathrm{s}$ の減少に伴って、印加電圧の正ピ 一ク付近で発生する交流部分放電電流の正パルスの発生数, 最大放電電荷が増加する。負パルスについては特に顕著な 変化は認められない。

(b) $15 \mu \mathrm{m}<\mathrm{s}<1 \mathrm{~mm}$ の領域： $\mathrm{s}$ が変化しても交流破壊電圧は ほとんど変化しない。また、交流部分放電の正パルスの発 生特性も顕著な変化は認められない。

最後に本研究を行うにあたり、実験に協力していただい た本学学生の林幸男君ならびに鶴水達也君に感謝いたしま す。

（平成 5 年 9 月 24 日受付）

\section{文 献}

（1）電気学会技術報告 "有機複合材料の電気・電子絶縁へ の適用技術の動向” 有機複合材料の電気・電子絶縁へ の適用調查専門委員会編電気学会 出版準備中

（2）中野, 三井：“機器絶縁における界面効果”平成 5 年電 気学会全国大会, S. 4-6, 1994
(3) Kiichi Yagisawa, Takashi Karasaki, Yasuo Ozawa, Masayuki Yamaguchi, Yasuo Sekii and Masayuki Kobayashi: "Development of Extrusion Type Molded Joint for $275 \mathrm{kV}$ and 500k XLPE Cables" HITACHI CABLE REVIEW, pp.9- 14, No.9, August, 1990.

（4）勝田, 吉久, 宮下, 加藤, 霜村：”CVケーブル用モールド形 接続部の界面について” 電気学会誘電・絶縁材料研究 会資料 DEI-92-13， 1992

（5）例えば、H.C.Miller: "Surface Flashover of Insulators" IEEE Trans. on EI, Vol.24, pp.765-786, 1989.

(6) Y.Yamano, S.Kobayashi and T.Takahashi: "Improvement of flashover strength and reduction of surce chargeinduced electric field enhancement of insulating material" IEEE Trans. on EI, Vol.EI-20, No.3, pp.529-536, 1986.

(7) D.W.Auckland, A.B.Borishade and R.Cooper: "The Electric Strength of a Narrow Column of Air Bounded by a Dielectric Wall" CEIDP, pp.472-477, 1974.

(8) A.B.Borishade: "The Development of Electrical Discharges in Simulated "Tree" Channels" IEEE Trans. on EI., Vol.EI-12, No.5, 1977.

（9）藤田, 能登, 吉村： "トリーを模擬したPMMA細管中の放 電電圧よトリーの伸びの関係”電気学会絶縁材料研 究会資料 EIM-88-41, 1988

(10)H.H.Hull: "A method for studying the distributon and sign of static charge on soild materials" J. Appl. Phys., vol.20, pp.169-170, 1949.

山野 芳昭 (正員) 昭和 26 年 3 月 17 日生, 51 年 3 月東

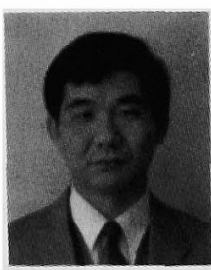
京農工大学大学院工学研究科修了。同年 4 月東洋紡績 (株) 入社。55年 6 月同社退社。 同年同月東京農工大学工学部助手。平成 2 年 4 月干葉大学教育学部講師, 現在同助教 授。工学博士。主として電気絶縁工学, 静電 気工学の研究に従事。平成 2 年電気学会論 文賞受賞。電子情報通信学会, 静電気学会、IEEE会員。 